\section{Volume 55}

Number 2

May 1988

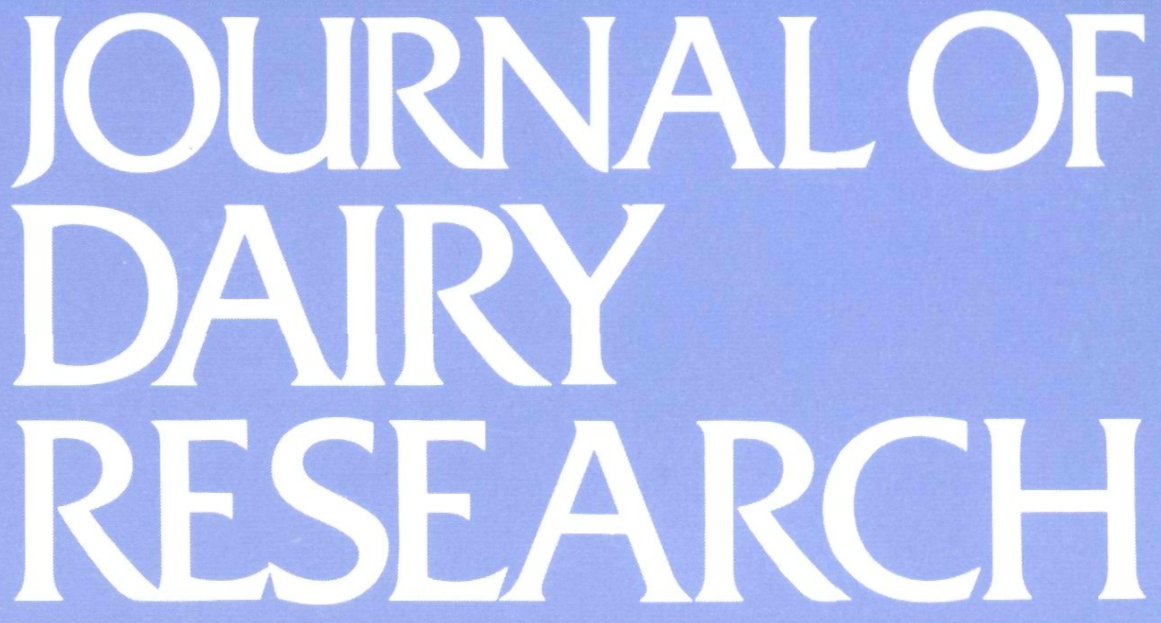

\section{DAIRYING}

LACTATION

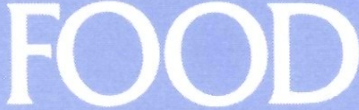

Cambridge University 
Editors: M. ElisABETH SHARPE, AFRC Institute of Food Research, Reading Laboratory, Shinfield, Reading RG2 9AT, UK

W. MAnson, Hannah Research Institute, Ayr, KA6 5HL, UK

Assistant Editors: B. F. BONE, MARY C. A. GRIFFIN, C. J. WILDE

Editorial Assistants: DOROTHY SKIDMORE, B. GILLIAN DAY

Secretary: L. C. FITZGERALD

The Journal was established in 1929 as a medium for the publication of the results of original research in dairy science and cognate subjects. It is published by the Cambridge University Press.

The subscription to volume 55, 1988, of the Journal of Dairy Research (ISSN 0022-0299) is $£ 88.00 \mathrm{UK}, £ 92.00$ elsewhere (USA and Canada US $\$ 215.00$ ) for a volume of four parts published quarterly in February, May, August and November. Single copies may be purchased at $£ 23.50$ net (USA and Canada US \$59.00) each, plus postage. Orders, which must be accompanied by payment, may be sent to any bookseller or to Cambridge University Press, The Edinburgh Building, Shaftesbury Road, Cambridge CB2 2RU. Subscribers in the USA or Canada should send their orders to Cambridge University Press, 32 East 57th Street, New York, NY 10022. Second class postage paid at New York, NY and at additional mailing offices. POSTMASTER: send address changes in USA and Canada to Journal of Dairy Research, Cambridge University Press, 32 East 57th Street, New York, NY 10022.

\section{(C) Proprietors of Journal of Dairy Research 1988}

Copying. This journal is registered with the Copyright Clearance Center, 27 Congress Street, Salem, MA 01970. Organizations in the USA who are also registered with CCC may therefore copy material (beyond the limits permitted by sections 107 and 108 of US Copyright law) subject to payment to CCC of the per-copy fee of $\$ 5.00$. This consent does not extend to multiple copying for promotional or commercial purposes. Code 0022-0299/88 \$5.00+.00.

ISI Tear Sheet Service, 3501 Market Street, Philadelphia, PA 19104, USA, is authorized to supply single copies of separate articles for private use only.

For all other use, permission should be sought from Cambridge or the American Branch of Cambridge University Press.

Back Volumes. Enquiries about the price and availability of back volumes should be sent to the publishers.

Claims for the replacement of journals believed to have been lost in transmission will only be entertained if made immediately upon receipt of the subsequent issue. 


\section{Erratum}

Review article. Fermented milks and their future trends.

\section{Microbiological aspects}

BY VALERIE M. MARSHALL

Journal of Dairy Research (1987), 54, no. 4, pp. 559-574

The reactions at the end of the heterolactate fermentation pathway in Fig. 1 should read as follows

Acetyl $\mathrm{CoA} \stackrel{\mathrm{NADH} \longrightarrow \mathrm{NAD}}{\longrightarrow}$ Acetaldehyde $\stackrel{\mathrm{NADH} \longrightarrow}{\longrightarrow} \stackrel{\mathrm{NAD}}{\longrightarrow}$ Ethanol 